\title{
Transnational entrepreneurship: opportunity identification and venture creation
}

\author{
Heléne Lundberg ${ }^{1}$ (D) Anneli Rehnfors ${ }^{1}$
}

Published online: 17 April 2018

(C) The Author(s) 2018

\begin{abstract}
The present case study focuses on entrepreneurs who have migrated from one developed economy (Sweden or Finland) to another developed economy (Hong Kong Special Administrative Region (HKSAR)). In contrast to the dominating understanding, we find that the transnational entrepreneurial incentives were opportunity driven rather than necessity based. The opportunity types identified varied, but indicate the importance of service opportunities, a type often left out of studies and classifications. A prevalent characteristic of transnational entrepreneurship is opportunity recognition based on introducing processes or products to the country of residence, familiar from the country of origin or based on use of the entrepreneurs' contacts in the home country. This study showed, however, that although this was the case for two entrepreneurs, some identified opportunities for acting in the opposite direction, or did both import and export. Notably, there was also a fourth category, offering businessfacilitating services, bridging differing cultural contexts in relationshipmiddlemen positions. For these entrepreneurs, there was thus no obvious "domestic market" from the start as assumed in traditional internationalization theories. Furthermore, although their businesses started on a limited scale between two countries, they quickly grew and entered other country markets. These transnational businesses thus represent forms of born globals not included in the high-tech business models often associated with such firms. Our findings finally lend support to arguments that a business-favorable institutional environment facilitates and encourages entrepreneurship.
\end{abstract}

Keywords Transnational entrepreneurship - Opportunity type - Institutional environment · Immigrants $\cdot$ Service $\cdot$ Relationship-middlemen position $\cdot$ Born global

Heléne Lundberg

helene.lundberg@miun.se

1 CER, Department of Business, Economics and Law, Mid Sweden University, Sundsvall, Sweden 


\section{Introduction}

Internationalization is occurring on several levels in the globalizing world of our times. There are internationalizing enterprises, but also a vast flow of individuals migrating to other countries. In learning to master institutional and cultural differences between the country of origin (COO) and the country of residence (COR), opportunities for venture creation may be identified and developed by migrants. This form of entrepreneurship is usually neglected in traditional internationalization research (Drori et al. 2009), but transnational entrepreneurship addresses this topic, that is, "entrepreneurial activities that are carried out in a cross-national context, and initiated by actors who are embedded in at least two different social and economic arenas" (Drori et al. 2009, p. 1001).

Transnational entrepreneurship deals with first-generation immigrants and represents a specific type of entrepreneurship in the sense that the first business exchange usually takes place between the entrepreneur's COR and COO. The choice of market is thus neither the result of serendipity or an unsolicited request from a country market (Merrilees et al. 1998) nor a result of formal screening and planning (Delmar and Shane 2003). It is, rather, an economic behavior resulting from knowledge of two different institutional and cultural contexts (Welter 2011). A transnational entrepreneur can, for instance, import products from the COO to the COR (e.g., Aliaga-Isla and Rialp 2012).

Although entrepreneurs are constantly scouting for opportunities in their environments (Hilmersson and Papaioannou 2015), the context has rarely been studied in connection with opportunity recognition (Lee 2015). Since the institutional context constitutes a significant factor in the progress of immigrant entrepreneurship, it should be taken into account (Aliaga-Isla and Rialp 2013). Most studies have focused on migrants moving from less-developed economies to developed economies (Aliaga-Isla and Rialp 2013). The case study reported on in this paper therefore adheres to the call for qualitative studies addressing other contexts (Aliaga-Isla and Rialp 2013) by focusing on migrants from two developed Nordic economies (Sweden and Finland) now living in a developed economy in Asia (the Hong Kong Special Administrative Region (HKSAR)).

Furthermore, the immigrant entrepreneurship literature devotes little attention to international entrepreneurial opportunities (Vinogradov and Jørgensen 2017). Although transnational entrepreneurship as a phenomenon is not new (e.g., Kyle 1999), we still lack knowledge on the opportunity identification process, opportunity types, and why transnational entrepreneurs choose to start particular types of ventures (Sequiera et al. 2009; Aliaga-Isla and Rialp 2013). Moreover, the literature at present tends to describe immigrant entrepreneurs as being driven into their entrepreneurship by negative circumstances, such as lack of knowledge and unemployment - in other words, entrepreneurship by necessity rather than in response to an opportunity (Aliaga-Isla and Rialp 2013). It has also been noted that in the literature on immigrant entrepreneurship, their firms are assumed to be small and unimportant (Dana and Morris 2007; Sequeira et al. 2009). In a multilevel approach aiming to deepen our understanding of the process of opportunity identification and the varying types of opportunities developed into born global firms by transnational entrepreneurs, the present study explores individual characteristics of seven transnational entrepreneurs, the types of opportunities (firms) developed, and the impact of the institutional and cultural contexts they acted within. The findings contribute to internationalization theory in general, but also to the 
emerging field of transnational entrepreneurship, by providing a more nuanced picture of transnational entrepreneurs, opportunity types, and born global ventures. In the following, theoretical considerations are presented, followed by the research approach of the present study, its findings, and finally, a section presenting a discussion and conclusions, including limitations and managerial implications.

\section{Theoretical considerations}

\section{Opportunity identification}

Entrepreneurship originates in opportunity development. Some opportunities are located or discovered, while others result from a creative process emerging from the entrepreneur's ideas and visions (Zahra et al. 2005). The opportunity concept is thus generally related to value creation and competitive imperfections, and it has been divided into two main types: innovation opportunities (related to creation) and arbitrage opportunities (related to alertness and discovery of market imperfections) (Mainela et al. 2014; Kirzner 1973). In either case, opportunity recognition is regarded as a key aspect of the entrepreneurial process (Mainela et al. 2014; Shane and Venkatamaran 2000). The opportunity concept is nevertheless often applied without much precision; at times, even a definition is lacking (Mainela et al. 2014). It has, however, been argued that international entrepreneurship focuses on outgoing entrepreneurial activity, while immigrant entrepreneurship mainly deals with incoming entrepreneurial activity (Emontspool and Servais 2017; Etemad 2004). It has also been argued that the more tangible the offer is (e.g., goods vs. service), the more likely the firm is to internationalize (Cloninger and Oviatt 2007). Within transnational entrepreneurship, four different firm types have been discussed: financial services, import/export of raw materials or goods, cultural enterprises, and manufacturing firms (Zhou 2004).

In the internationalization literature, few empirical studies have addressed the process of opportunity identification and development, and the contributions from entrepreneurship research suffer from a largely domestic focus in this respect (Chandra et al. 2009). Furthermore, although individual characteristics are regarded as key to internationalization (Jones et al. 2011), international entrepreneurship has seldom focused on the individual entrepreneurs themselves (Sequiera et al. 2009; Drori et al. 2006). Entrepreneurial qualities seem to be influenced by the experiential impact of the upbringing, the environment, and the education and work experiences, resulting in possession of certain knowledge and capability to recognize, manage, and act on entrepreneurial opportunities (Shane 2000). Interaction with experienced entrepreneurs can, for instance, convey a message that starting a business is a career option and that opportunities may be worth paying attention to (Gnyawali and Fogel 1994). Likewise, discussions with family and friends can prepare individuals for entrepreneurship (Shane 2003). In the case of transnational entrepreneurs, the immigration experience is usually related to their venture creation (Drori et al. 2006).

It has furthermore been argued that relevant prior knowledge is key to opportunity recognition (e.g., Shane and Venkataraman 2000). Knowledge can be gained in two ways: experientially from acting on an opportunity or from others (Eriksson et al. 
1997). Eriksson et al. identified three types of experiential knowledge in an international business context: experiential knowledge of clients, the market, and competitors (foreign business knowledge); experiential knowledge of government, institutional frameworks, rules, norms, and values (foreign institutional knowledge); and experiential knowledge of the firm's capability and resources to engage in international operations (internationalization knowledge). Taken together, they have been called a person's international orientation (Dichtl et al. 1990). The third type is only in play if the entrepreneur, or any employee in a leading position, has previous experience of conducting international business. As the type and depth of knowledge varies between individuals, each person is characterized by a certain knowledge corridor that decides whether opportunities can be identified or not - and if so, how they will be judged (Shane 2000; Venkataraman 1997). A transnational entrepreneur may have foreign business knowledge from previous work or travel experiences and has institutional knowledge of at least two contexts (COO and COR). There is thus a certain international orientation from the start.

In terms of knowledge developed by learning from others (Eriksson et al. 1997), human capital, often measured as years of formal education, is often used as a predictor of an individual's ability to identify and develop entrepreneurial opportunities (Shane 2003; Vinogradov and Kolvereid 2007). However, in the immigrant entrepreneurship literature, reports on empirical evidence of the effect of human capital on immigrants' propensity to start a business are contradictory (Vinogradov and Jørgensen 2017). It seems likely that individuals born and raised in a developed economy have a personal history, and thus a human capital, that differs from that of individuals born and raised in a less-developed economy.

The ability to comprehend cultural differences and adapt one's behavior (Johanson and Vahlne 2009) has furthermore been studied through the concepts of a global mindset, cultural intelligence, and cross-cultural competence (Zahra et al. 2005). It has been shown that increased knowledge and experience expand the capability of managing institutional contextual influences, and that embeddedness in the foreign context boosts the cultural intelligence of entrepreneurs, forming an international mindset and personal cross-cultural competence (Zahra et al. 2005; Johanson et al. 2006). Furthermore, as a result of confronting two different contexts, cognitive alertness capabilities (Kirzner 1979) for effective scanning and interpretation of international opportunities also develop. The migration experience can thus give transnational entrepreneurs an extraordinary creative, social, and cultural capital (Terjesen and Elam 2009), resulting in a more cosmopolitan constitution of transnational identity (Wong and $\mathrm{Ng}$ 2002). Bridging different national contexts has been found to be favorable for opportunity recognition and venture creation (George et al. 2016). More specific knowledge is, however, required regarding how the personal history of the transnational entrepreneur and the contexts represented by the COO and COR affect the type of opportunity identified and the further development of the created venture.

\section{Transnational ventures}

As a field of practice, international entrepreneurship has a far-reaching history (e.g., Kyle 1999), but the scholarly counterpart is quite recent (Etemad 2016). The process model, developed by Johanson and Vahlne in 1977, has been very influential. It 
proposes that a firm enters a new market gradually and only after securing a position in its domestic market. In this process, reactive experiential learning about foreign markets is the key, since it reduces uncertainties associated with entering a new country market. Furthermore, firms are expected to start their internationalization with foreign markets that are close to the domestic market in terms of psychic distance, defined as "factors that make it difficult to understand foreign environments" (Johanson and Vahlne 2009, p. 1412). The process model (Johanson and Vahlne 1977) was later merged with a network perspective (Johanson and Mattsson 1987; Johanson and Vahlne 2009) into viewing internationalization as a process, whereby a firm establishes and develops its foreign market positions through its foreign network partners. However, in entering a foreign market's network, a liability of network outsidership will be a major source of uncertainty.

Network studies have repeatedly shown that relationship development is a time- and effort-consuming process (Johanson and Vahlne 2009). Relationships, both business and private, are hard to copy and may therefore represent important and valuable firm assets (Dyer and Sing 1998). Johanson and Vahlne (2009, p. 1414) further underline that "the larger the psychic distance, other things being equal, the more difficult it is to build new relationships," due to the so-called liability of foreignness (Hymer 1976; Zaheer 1995). The liability of foreignness is usually defined as "arising from the unfamiliarity of the environment, from cultural, political, and economic differences, and from the need for coordination across geographic distance, among other factors" (Zaheer 1995, p. 341).

In sum, these perspectives view the first step of internationalization as entering an unfamiliar foreign market from a base in the COO. There is thus a domestic operation in the $\mathrm{COO}$ from the start. By contrast, transnational entrepreneurship addresses entrepreneurship originating in two known country markets, often in the form of export from the well-known COO to a fairly well-known COR. The transnational entrepreneur thus acts internationally from the start. The applicability of traditional (gradual) international entrepreneurship theory on transnational entrepreneurship can therefore not be taken for granted.

\section{Born globals and international new ventures}

In the 1990s, the gradual internationalization process, initiated after a period of domestic operation, was questioned in the light of reports on so-called born globals (Rennie 1993), that is, firms characterized by having export as the primary goal of the firm soon after, or even from, its inception, and so-called international new ventures, "business organizations that, from inception, seek to derive a significant competitive advantage from the use of resources and sale of outputs in multiple countries" (Oviatt and McDougall 1994, p. 49). Later, Knight and Cavusgil (2004, p. 124) presented an often-cited definition of born globals: "business organizations that, from or near their founding, seek superior international business performance from the application of knowledge-based resources to the sale of outputs in multiple countries." Born global firms are often described as highly innovative, with global technology competence (e.g., Freeman et al. 2006; Knight and Cavusgil 2004; Moen and Servais 2002; Rennie 1993). 
Transnational entrepreneurship implies creating a born global firm from inception. Taken together, the dominating definitions of born global and international new venture encompass seven criteria (Welch et al. 2016): (a) early commencement of internationalization, (b) competitive advantage/performance as the motive, (c) use of resources outside one's home country, (d) sale of outputs outside one's home country, (e) operation in multiple countries (geographical spread), (f) small size, and (g) technology orientation. Notably, transnational enterprises fulfill all these criteria, except perhaps technology orientation. However, the "home country" part of the definition presupposes that the entrepreneur is acting from his/her COO, which in transnational entrepreneurship is not the case. Transnational entrepreneurship thus has a lot in common with these "born global forms" of international entrepreneurship, but international entrepreneurship has seldom focused on the individual entrepreneurs themselves (Sequiera et al. 2009; Drori et al. 2006). By contrast, transnational entrepreneurship puts emphasis on the individual entrepreneur and on the impact of two specific institutional structures: the COO and the COR (Drori et al. 2009), often focusing on the entrepreneurs' contacts in the home country (Portes et al. 2002).

In addition to transnational entrepreneurship, a number of similar fields have emerged, focusing on ethnic, international ethnic, or diaspora entrepreneurs (e.g., Aldrich and Waldinger 1990; Elo and Riddle 2016; Kloosterman 2000). It is noted, however, that instead of addressing entrepreneurial opportunities, research focusing on these entrepreneurs has mainly addressed ethnicity and "causes and consequences," such as self-employment, social networks, policy, gender, human capital characteristics, demographic factors, and history (Ilhan-Nas et al. 2011).

Transnational entrepreneurship is an emerging field that needs further research pinpointing the distinctive features of this form of entrepreneurship (Drori et al. 2009). Presently, almost all studies deal with immigration from less-developed countries to advanced economies (Aliaga-Isla and Rialp 2013). Furthermore, immigrant entrepreneurs are usually pictured as being driven into their entrepreneurship by negative circumstances, such as lack of knowledge and unemployment (Aliaga-Isla and Rialp 2013). Their entrepreneurship is thus often presented as a subsistence activity (Emontspool and Servais 2016; Meir and Baskind 2006; Viswanathan and Rosa 2007), and their firms are assumed to be small and unimportant (Dana and Morris 2007; Sequeira et al. 2009).

\section{Institutional and cultural contexts}

Answering to calls for contextualized studies of opportunity identification and development (e.g., Lee 2015), the present article considers international opportunity development as context-embedded. Contexts, that is, circumstances, conditions, situations, or environments that are external to a phenomenon and enable and constrain it, cut across levels of analysis (Welter 2010). Different nations' institutionalized arrangements of organizational, regulatory, and social contexts form disparate business systems. The transnational entrepreneur who is embedded in these institutional arrangements has to handle dual systems from the start, and the entrepreneurial actions and business operations are either hampered or supported by the systems (Tang 2008; Yeung 2002). Certain institutional aspects, such as stable political environments; simplified business laws; reduced bureaucratic requirements; fewer entry procedures; 
and modernized, efficient business registration, are seen as supportive for entrepreneurship and entrepreneurial opportunities (Klapper et al. 2004). Likewise, government support, government transparency, and legal rules positively affect international entrepreneurial capacity (Zhang et al. 2017).

Culture is generally defined as a set of shared values, beliefs, and expected behaviors (Hofstede 1980, 2010). Learning to master contextual influences of national culture(s) (Zahra et al. 2005) and gaining knowledge of business system(s) (Yeung 2002) and the "rules of the game" of the environment of a foreign country (Ilhan-Nas et al. 2011) requires learning and behavioral adaption (Johanson and Vahlne 2009). Environmental factors such as social and political regulatory contexts and cultural values affect entrepreneurs' processes of opportunity recognition (George et al. 2016) and impact on the behavior and processes of entrepreneurship within the "rules of game" of a country (Ilhan-Nas et al. 2011). In sum, "the institutional environment defines and limits entrepreneurial opportunities" (Burton et al. 2010, p. 10), but, surprisingly, international entrepreneurship research has not given much attention to the role of the institutional environment in opportunity identification and firm creation (Chiles et al. 2007).

\section{Research approach}

\section{The chosen method}

The present study is qualitative, based on the viewpoint of the entrepreneur (Pratt 2009) while also considering the importance of context for understanding (Welter 2011, 2012). The study objects (i.e., cases) are transnational entrepreneurs who have migrated from a developed economy to another developed economy. The case study design was chosen, as it covers a real-life environment and enables both cause-and-effect and indepth explanations (Yin 2013). The case study method is suitable for investigation of actions, such as opportunity recognition and development, in the environment where it takes place (Welch et al. 2011), as well as how opportunity recognition operates in a situation where behaviors cannot be manipulated through experimental design (Shane 2000). Further, the approach is common in recent studies in international entrepreneurship and transnational entrepreneurship, as well as in opportunity recognition research (Coviello 2006; Chandra et al. 2009; Hilmersson and Papaioannou 2015; Kontinen and Ojala 2011; Shane 2000; Terjesen and Elam 2009).

Multiple cases yield more robust theory than single-case research, as they enable comparisons among a variety of empirical evidence that can clarify whether findings are valid for more than one specific case (Eisenhardt and Graebner 2007). The chosen number of cases (7) is within the range (4-10) recommended by Eisenhardt (1989) for multiple-case studies.

Answering calls for further research on the individual level of transnational entrepreneurship (e.g., Sequiera et al. 2009), data gathering was conducted by semi-structured, open-ended interviews of individual immigrants starting a born global firm in their COR. According to Yeung (1995, p. 314), for "international business research, interviewing is probably the most useful and direct method. The beauty of this method lies in its validity (i.e., dealing directly with decision makers and the richness of 
information collected) and its reliability (i.e., replicable in practice)" and further, "the qualitative personal interview method performs its function as one of the best and most suitable methods in international business research in an Asian urban context."

In contrast to most transnational entrepreneurship studies, focusing on immigrants moving from developing countries into developed countries, four Finnish and three Swedish immigrant entrepreneurs in Hong Kong were chosen for this study. Although speaking different languages, these Nordic individuals come from societies with comparable educational, institutional, entrepreneurial, economical, regulatory, and cultural environments, Finland being under Swedish rule for almost 700 years (1157$1809 \mathrm{CE}$ ). The potential interviewees were identified through former contacts and the member list of the Swedish and Finnish Chambers of Commerce, based on the following criteria: first, the entrepreneur should have been living outside the COO for at least 1 year (Sasse and Thielemann 2005); second, the entrepreneur's firm should have been involved in international business from the start; third, the interviewee must have been running the business for at least three consecutive years in Hong Kong; and, finally, the firm should not be a subsidiary.

The chosen entrepreneurs represent SMEs acting internationally from their inceptions in Hong Kong. The entrepreneurial owners have been living in Hong Kong for 5 to 25 years and range in age from 29 to 57 years. Information about the entrepreneurs is summarized in Table 1 below.

The interviews were conducted in April-May 2016. An introductory letter by e-mail was followed by a Skype video-call interview. Conducting the interviews on Skype was a limitation; in that, it allowed for eye contact but not for a view of body language. An interview guide was developed (presented in full in Table 4). In addition to factual information about the firms and the entrepreneurs, the questions centered on their transnational entrepreneurship experience, such as opportunity recognition, opportunity type, level of internationalization of the company (e.g., inspired by Johanson and Martín 2015), and institutional environment (e.g., inspired by Tang 2008). The interviewees were given space to elaborate their thoughts in rich descriptions. The interviews lasted about an hour, and to enhance confirmability (Guba and Lincoln 1994; Lincoln and Guba 1985), they were recorded and transcribed verbatim. The participants were thereafter asked to confirm the transcripts of the recordings. The interviews were done in English, one of the two official languages of Hong Kong and the one used by the businesses. Conducting the interviews in English, the second language of both the interviewer and the interviewee, limited the ability to convey nuances but eliminated the need to translate the responses and risk making mistakes in that process.

After the first interview, the data were coded with open coding by the second author. Thereafter, the consecutive interviews were coded in same manner and compared with the categories of the previously collected and coded interview data. When the series of interviews was completed, there was a second reading of the material by the first author, checking the conceptualizing and categorizing of data and comparing the codes with those of previous studies. At this stage, the word-for-word interview data were imported into Nvivo, a computer-based analysis program. The original data were first coded according to the conceptual framework of the study, but the definitions were then allowed to arise from the data to reveal the special characteristics of the cases (Mainela and Puhakka 2009). Themes were sought within cases as well as in cross-case pattern searches (Terjesen and Elam 2009). The codes were not fixed but were continuously 


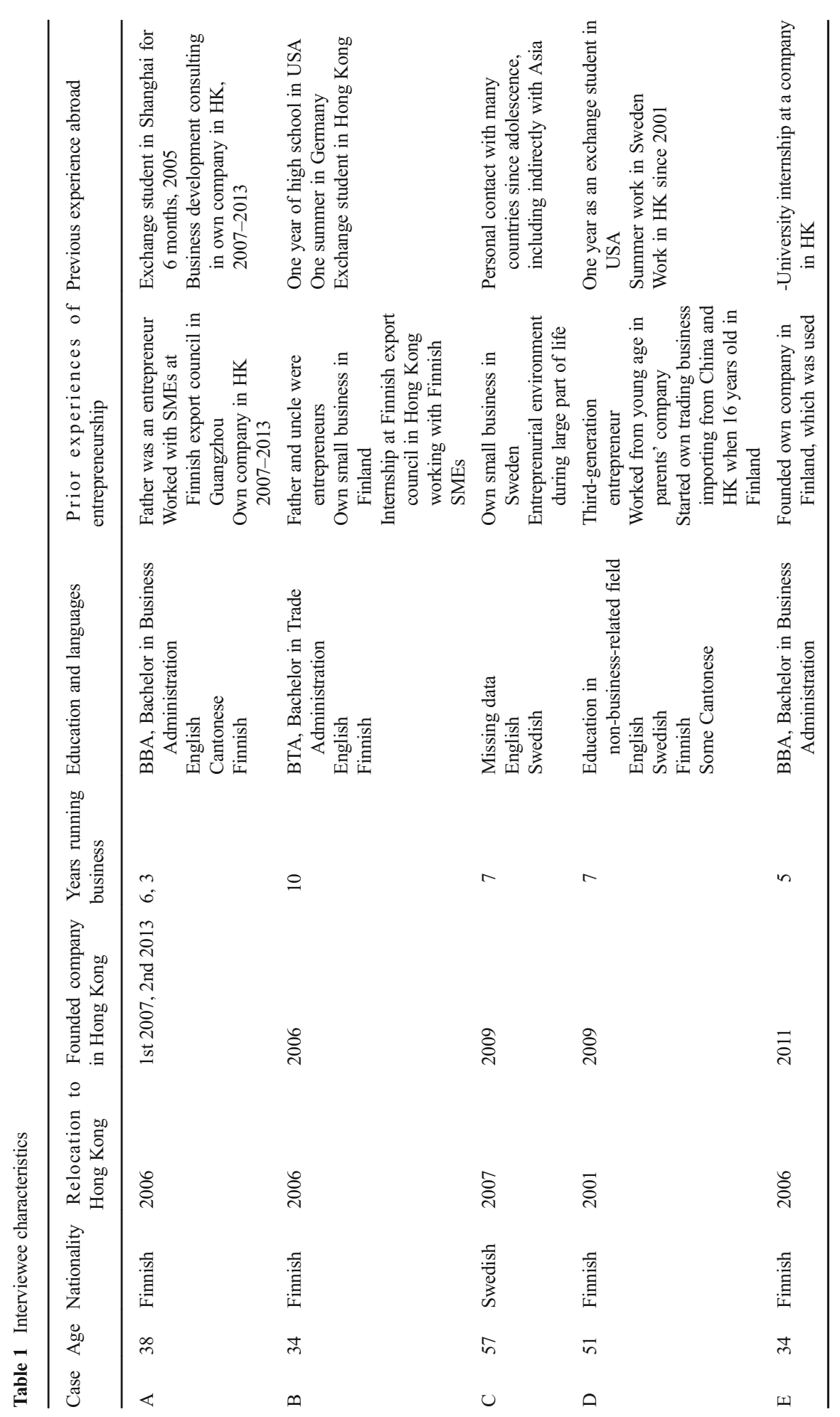




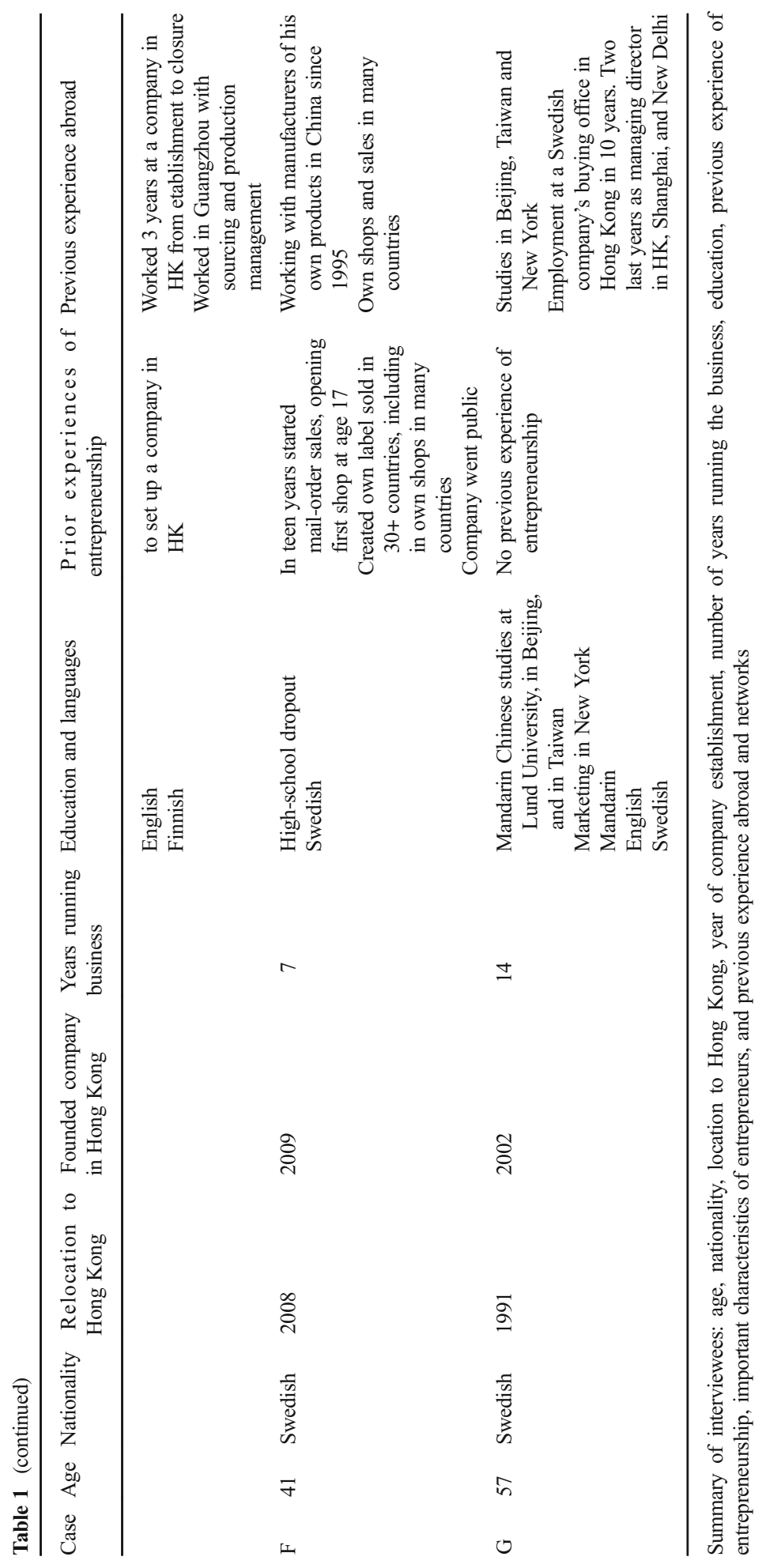


scrutinized and refined in an abductive process of successive iterations between theory and data (Dubois and Gadde 2002). Answering calls for multilevel analysis (Madsen and Servais 1997; Peiris et al. 2012), we looked for connections between the different levels of analysis (individual, firm, context) in order to create a context-sensitive understanding of the entrepreneurial behaviors. A selection of actual quotes from the protocols is presented in support of the related claims.

\section{The research context}

Reviewing the immigrant entrepreneurship literature, Aliaga-Isla and Rialp (2013) noted that almost all studies deal with immigration from less-developed countries to advanced economies and that Asia is represented by Australia only. Addressing these gaps, this study focuses on migrants relocating from one advanced economy to another and, adding to the range of Asian countries, Hong Kong was chosen as COR.

Hong Kong, officially Hong Kong Special Administrative Region (HKSAR), has been an autonomous territory since 1 July 1997, when sovereignty over Hong Kong was transferred from the United Kingdom to the People's Republic of China (PRC). "One country-two systems" alludes to the idea that within the territory of PRC, the main body of China uses a socialist system, but Hong Kong, Macau, and Taiwan use a capitalist system. The HKSAR government provides very fast business registration processes (Timmons and Spinelli 2004). It is seen as the least interventionist government in the world (Mok 2005), and entrepreneurial flexibility, alertness, and exploitation of opportunities are presented as underlying the dynamics of the HKSAR economy (Yu 1998). Moreover, the proximity of the mainland Chinese market attracts foreign firms and entrepreneurs to the city. Countless Hong Kong companies provide company secretarial services with accounting, auditing, patent, and banking services, including company incorporation and taxation, in both HKSAR and mainland China.

\section{Transnational entrepreneurship: Seven cases}

\section{Opportunity identification by transnational entrepreneurs}

Experiential knowledge in the form of foreign business knowledge and foreign institutional knowledge is expected to improve entrepreneurial qualities by resulting in a capability to recognize, manage, and act on entrepreneurial opportunities (Eriksson et al. 1997). According to Eriksson et al., education, that is, learning from others, is a way to gain business knowledge that facilitates starting and running a company. In the present study, however, although four of the entrepreneurs (A, B, E, G) had at least a Bachelors' degree, none of them put any great emphasis on the knowledge acquired through these studies: B described the education, rather, as "a brief introduction to business." Notably, A, B, E, and G had been studying in Asia and could therefore have been expected to acquire valuable knowledge about the Asian context in that way. However, their language proficiencies, substantial experiences of living and working/ studying abroad, extensive overseas travel, and prior employment/business experiences abroad indicate a high degree of international orientation (Dichtl et al. 1990) that may 
explain their view on the limited contribution of their education to their entrepreneurial capabilities. Almost all the entrepreneurs had some experience of other countries through studies, travel, or work. Also, they had either some (A, B, D, E) or extensive $(F, G)$ work experience in Asia prior to starting their businesses in Hong Kong that had resulted in foreign business knowledge as well as institutional knowledge. C, who followed a family member to Hong Kong, had international experience from previous work in the home country.

The majority of the entrepreneurs in this study also had some previous entrepreneurial experience, further facilitating the decision to start a company. Three entrepreneurs (A, B, D) grew up in an entrepreneurial environment with a close relative being an entrepreneur, for example, B: "There was that kind of role model, my uncle was an entrepreneur and I was looking up to him so maybe there was something that was growing inside me," and A: "My father had a small construction company so I have probably 'inherited' something from there."

Two of them (B, D) started their first businesses as youngsters in their COO, "I started a business when I was 16 years old... and was still at that business when I moved to Hong Kong" (D), and "I had a small business collecting golf balls at a nearby golf course. I washed the balls and sold them back to the players" (B). Without role models, entrepreneur F started his first business even while studying in the third year of high school and dropped out to sell his products by mail order. When he was 17, he opened his first shop. The other three $(\mathrm{C}, \mathrm{E}, \mathrm{G})$ did not have their own previous experience of entrepreneurship, but they had been employed in an entrepreneurial environment. The personal experiences of these individuals had developed entrepreneurial qualities (Shane 2000), and they saw transnational entrepreneurship as a career option (Gnyawali and Fogel 1994).

\section{Turning cultural challenges into a competitive advantage}

In addition to entrepreneurial knowledge, skills in managing cultural differences are required of entrepreneurs working in foreign countries, and especially so when there are large cultural differences. You can lose a customer by overstepping intangible business rules, as exemplified by D: "I learned that [in Hong Kong] you can lose business if you e-mail someone asking for a reply."

The transnational entrepreneurs of our cases were characterized by a global mindset, cultural intelligence, and cross-cultural competence (Zahra et al. 2005) resulting from spending time abroad in various countries, not the least in their new COR. Notably, only of them (F, with experiences of entrepreneurship from other parts of Asia) created a business upon arrival in the COR. Cross-cultural competence is not accessed overnight. Some cognitive and normative cultural differences may remain unnoticed for some time and only emerge and become actualized in meetings with people in business situations.

The Hong Kong people, they look Chinese, but behave like the Western people-but then they are suddenly super Chinese, with very deep Chinese values and so on. It was a little bit difficult to categorize them in the beginning... Hong Kong people are mixed, in between East and West. (E) 
When I came to Asia I didn't pay any attention to the culture differences... When I started my own Hong Kong business and really started to do sales and businessdeveloping work in Mainland China with Chinese customers, then there were a lot of cultural clashes. (A)

With time, a deeper understanding of the impact of cultural normative issues and differences in running a company are revealed and adapted to, as illustrated by B:

In Hong Kong the partners and employees, they listen to you, they listen to you very carefully, and they pretend to agree with you, but that means nothing, for nothing really happens. It takes quite a long time to understand when things actually are progressing and when nothing is happening - I guess two or three years until you get it and understand how you should manage things, if you want the things to be done.

For A, the East-West meeting was facilitated by a partnership:

I have already spent a decade in China and my Chinese co-founder has been a decade in the US, so we both understand a little bit of the culture of the other side. That has been really helpful.

F, who had been doing business in Asia since 1995, summarized an insight that was expressed by all the informants: "After many years, I understand that there are so many more layers that it is very difficult to understand." Over time, the personal experiences and capabilities of these entrepreneurs reduced the liability of foreignness (Hymer 1976; Zaheer 1995). They understood and could manage local business practices and customs and knew how to interact with local parties such as employees, customers, and suppliers. These capabilities reduced the risk of misunderstandings and conflicts and allowed them to bridge the psychic distance (Johanson and Vahlne 2009). In the next step, their cross-cultural bridging abilities (Piaskowska and Trojanowski 2014) could be leveraged for entering other foreign markets as well.

A cross-cultural bridging ability is not enough, though. Many individuals with this ability never think of starting a business. In these cases, however, their international orientation and entrepreneurial qualities meant that the entrepreneurs had the cognitive wherewithal to identify this ability as a competitive advantage that represented a business opportunity, and they saw themselves as having knowledge enough to make this opportunity into a successful business venture.

Four influences driving the early internationalization of firms have been suggested: entrepreneurial, business, location, and network-specific factors (Zucchella et al. 2007). In addition, these cases indicate that the cross-cultural bridging capability of transnational entrepreneurs is an important dimension at the individual level.

\section{Transnational entrepreneurship opportunities and ventures}

Three entrepreneurs (C, D, G) came to Hong Kong for work reasons, and only one of them, C, had an intention to start a business from the beginning: "I just thought I'd start my own business" (C). Like entrepreneur B, C found an arbitrage opportunity in selling products from Asia to the COO. D imported products from Nordic countries to help a 
friend and saw a potential to create his own business. Informant $G$ lost her job and considered moving back to Sweden, but realized that staying in Hong Kong implied easy access to the rest of Asia. She identified a niche for companies without their own buying office and a possibility to provide them with services similar to what she had been doing at her job. She thus found a way to turn work experiences into her own business. "I was kind of looking forward to trying myself - if I could be successful in running something according to how I wanted to ... serve customers and do my own business. That is why I decided to stay." Entrepreneurs A and F also saw opportunities to sell services to firms in the COO. The initial intention of entrepreneur A was to do consultations and business development, but that changed after 5 years when he met a Chinese man with whom he started a new international business venture assisting exporters in his COO. Entrepreneur F relocated to Hong Kong with the intention to open a new business: "basically the reason to come to Hong Kong was... to work outside the Scandinavian and Swedish market right away." Forming a venture was for these entrepreneurs not a last resort or a means to survive, but rather an exciting opportunity. In contrast to previous findings in the context of ethnic entrepreneurship (Aliaga-Isla and Rialp 2013), their decisions to become entrepreneurs were driven by opportunity rather than by necessity. The opportunities identified were strongly related to their previous work or personal experiences, and the opportunities they developed are accordingly of varying nature (see Table 2 below).

Table 2 shows that these entrepreneurs all have business relations with their COO, but in varying forms. Four of them (A, B, C, D) developed export opportunities, initially to the $\mathrm{COO}$, but later also to other markets, with $\mathrm{A}$ and $\mathrm{D}$ combining export with import. Company A initially sourced industrial design in Finland, selling it to China, while D imported materials and technology from the Nordic countries.

Table 2 First opportunity characteristics

\begin{tabular}{|c|c|c|}
\hline Interviewee & Opportunity recognition & Opportunity type \\
\hline $\mathrm{A}$ & $\begin{array}{l}\text { Consulting firm: help technology companies with something } \\
\text { to sell to producers in China }\end{array}$ & $\begin{array}{l}\text { Assist firms in } \mathrm{COO} \text { with selling } \\
\text { to COR }\end{array}$ \\
\hline $\mathrm{B}$ & $\begin{array}{l}\text { Privately bought a web camera in HK that was of very good } \\
\text { quality; could sell such equipment on the Finnish } \\
\text { equivalent of eBay, Huuto.net }\end{array}$ & $\begin{array}{l}\text { Arbitrage between COR and } \\
\text { COO }\end{array}$ \\
\hline $\mathrm{C}$ & Export & $\begin{array}{l}\text { Arbitrage between COR and } \\
\text { COO }\end{array}$ \\
\hline $\mathrm{D}$ & $\begin{array}{l}\text { Started importing materials for a friend in HK, and then with } \\
\text { him started a business to develop quality houses in a } \\
\text { Nordic standard }\end{array}$ & $\begin{array}{l}\text { Trading a different standard of } \\
\text { materials from } \mathrm{COO} \text { to } \mathrm{CO}\end{array}$ \\
\hline $\mathrm{E}$ & $\begin{array}{l}\text { Production management (sourcing and quality control) in } \\
\text { China for Finnish customers }\end{array}$ & $\begin{array}{l}\text { Assist firms in } \mathrm{COO} \text { with } \\
\text { production in COR }\end{array}$ \\
\hline $\mathrm{F}$ & $\begin{array}{l}\text { Services: product development, compliance, recruiting, } \\
\text { design, quality control, etc. }\end{array}$ & $\begin{array}{l}\text { Assist firms in } \mathrm{COO} \text { with } \\
\text { production in } \mathrm{CO}\end{array}$ \\
\hline G & $\begin{array}{l}\text { Saw a niche for companies without their own buying offices } \\
\text { out here: that they would need services like quality } \\
\text { control, sourcing, and compliance auditing }\end{array}$ & $\begin{array}{l}\text { Assist firms in } \mathrm{COO} \text { with } \\
\text { production in COR }\end{array}$ \\
\hline
\end{tabular}


Company B mainly exports products from China to customers in the COO. The cultural differences are apparent at the company level, and the adaptation to the business culture is even distinguishable in entrepreneur B as a person:

I stopped believing in things, stopped having so many expectations. Some kind of "I believe when I see" approach... You need to make controls every week and every month.

Manufacturing products in China entails similar cultural issues for exporter C. For both these exporters, the COO remains their main market, with $75 \%$ (C) and $95 \%$ (B) of total sales.

The three service providers (E, F, G) mainly work with mainland China manufacturers. They started with customers from their $\mathrm{COO}$ but have expanded their customer base to other markets as well. The customers of F are from several European countries, the USA, and Australia and are served by 32 employees. Company $\mathrm{G}$ is just opening an office in India, working with services other than those they provide on the Chinese market, and have customers all over Asia. They have 10 employees in Hong Kong. One of the companies (E) has located its office across the border in mainland China, and four of its six employees are Chinese.

The other companies (F, G) have hired both Hong Kong Chinese and mainland Chinese employees. Most of their business is conducted in China. In the serviceproviding companies, one of the Nordic owners speaks Cantonese (E) and one speaks Mandarin Chinese (G), which facilitates their work, but, as stated by E, "Language is not really the issue; culture is a bigger issue, I would say, in our operation." All three have mainland China as their main market, with E, 95\%; F, 100\%; and G, $80 \%$ of their total sales on the Chinese market. Table 3 provides a summary of the firm characteristics.

We find that moving from northern Europe to Hong Kong and doing business in Hong Kong and mainland China has meant encountering cultures that are very different from the COO. Getting to know the COR has, in combination with their international orientation and entrepreneurial qualities, resulted in cognitive capabilities to spot both arbitrage and service opportunities for business exchange between these countries (Zahra et al. 2005). Their business did, however, not rest at that stage. As shown in Table 3, they have all identified opportunities to include other markets as well. They thus fulfill the commonly used criteria for born globals, although acting outside the high-tech area of business (Welch et al. 2016). In total, they now employ 103 employees in several countries, including their COR and their COO. This contribution to economic development, not the least of both their $\mathrm{COR}$ and $\mathrm{COO}$, further underlines the economic potential of transnational entrepreneurship.

\section{The institutional and cultural context of Hong Kong}

The entrepreneurs in the study all find the Hong Kong institutional environment very entrepreneur friendly.

When you are dealing with the Government-it's efficient, it's very structured, there is no corruption. You read on websites what you should do and then that's the way it works. So it's a very uncomplicated, transparent place for business... There's not much administration. (G) 


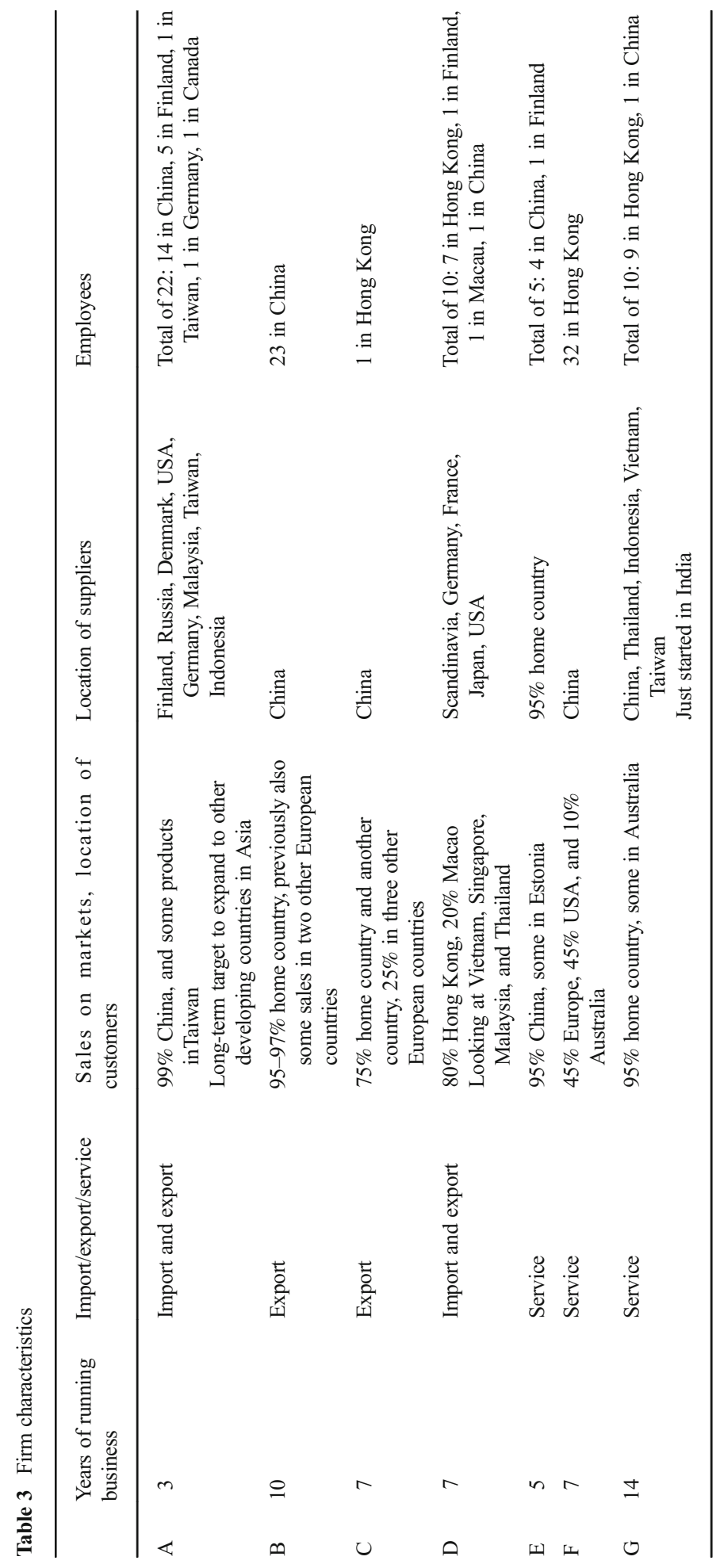


Hong Kong is experienced as a dynamic society where business and entrepreneurship are appreciated and supported. "The people give support," said G, and E explained that advice and help is offered without one owing anything in return:

Hong Kong is a very dynamic society and people help other people a lot — when you meet somebody and you talk about business, they often say, "hey, I know somebody who can help you," and then they call them for you immediately and that's amazing. And they are not requiring anything in return... It's great. I love it! (E)

The entrepreneurs found it easy to start the business, not the least administratively, as there are plenty of companies acting as corporate service providers. They consider it more convenient than the way the same things are done in the home countries:

A big difference is how fast different things can be put into action. I would say it was a little like night and day. (C)

It is very simple, you can start a company in the morning and have your bank account opened. It is up and running right away and you can start to invoice in the afternoon. (F)

Five of the entrepreneurs have experience of entrepreneurship in their home countries, and one of them $(\mathrm{G})$ is just setting up a company there. The Finnish entrepreneurs find that Hong Kong has fewer rules and regulations, is less bureaucratic, and does not burden the enterprise with administrative duties to the same degree as in Finland:

In Hong Kong, the Government does not interfere in your business... Finland has so many rules about everything and it's very complicated for a new company... and lots of bureaucracy, which means constant efforts for you all the time. (E)

The Swedish entrepreneurs think that setting up a company in Sweden has been made easier and more straightforward, but still is more expensive than in Hong Kong. Also, hiring people is seen as more complicated, requiring more commitment, costs, and administration. The bureaucracy and processing times in Sweden were also highlighted: "much more cumbersome, more bureaucracy, much longer processing times" (F).

While incorporation is seen as a positive experience, the institutional environment has its weak sides, according to some (D, F) of the entrepreneurs.

In Hong Kong, when the people are doing something they are used to and there is a clear protocol, it's very efficient, but if there ever is a situation where people don't know how — or what — to do, or there is not a protocol, it can be a little bit complicated. (F)

But overall (A, B, C, D, E, G), the stance of the government is experienced as supportive, allowing them to concentrate on entrepreneurship. The government may also give financial support to entrepreneurs: "When I participated at an exhibition, the Hong Kong government funded 50\% of the cost. Hong Kong is particularly business friendly and flexible" (C).

The entrepreneurs in these cases thus found it easy to interact with the Hong Kong authorities and to learn the rules of the game (Ilhan-Nas et al. 2011), which facilitated 
starting a business. These findings therefore further underline that the regulatory context can facilitate entrepreneurship by being transparent and supportive (Baumol et al. 2007; Tang 2008; Yeung 2002). Using the supportive context of Hong Kong, they all operate on the mainland Chinese market, which institutionally would cause much greater challenges if they were to locate their businesses there.

\section{Discussion and conclusions}

\section{The transnational entrepreneur}

International entrepreneurship research has seldom focused on the individual entrepreneurs (Cumming et al. 2009; Drori et al. 2006). As well, within the realm of transnational entrepreneurship, studies addressing the individual have been called for (e.g., Elo and Freiling 2015), since individual characteristics are regarded as key to internationalization (Jones et al. 2011). Paying attention to differences among transnational entrepreneurs, instead of treating them as a homogeneous group (Westhead et al. 2001), improves the indepth understanding of their entrepreneurial processes and increases the predictive and explanatory power of transnational entrepreneurship models. Aiming to deepen our understanding of the process of opportunity identification and the varying types of opportunities developed by transnational entrepreneurs, the present study therefore explores individual characteristics of seven transnational entrepreneurs, the types of opportunities (ventures) developed, and the impact of the institutional and cultural contexts they acted within.

One's personal background, in the form of education and prior experiences, has been seen as formative for an individual's mindset, and the resulting knowledge is regarded as a key aspect of entrepreneurial qualities (Shane 2000; Welch and Luostarinen 1988). The findings of this study confirm this, showing that five out of seven informants (A, B, $\mathrm{C}, \mathrm{D}, \mathrm{F}$ ) had a formative string emerging from previous experiences as entrepreneurs or from an entrepreneurial environment, indicating a positive stance about how to be and act and how to make a living as an entrepreneur. They furthermore had some business knowledge to start with, as well as knowledge of the institutional context of the COR from living and working there before starting their companies. There was thus valuable experiential knowledge (Eriksson et al. 1997) from the start. Their human capital is likely to facilitate identification of a broader range of opportunity types compared with migrants possessing lesser human capital.

Human capital, operationalized as years of formal education, has often been used as a predictor of an individual's ability to identify and develop entrepreneurial opportunities (Shane 2003; Vinogradov and Kolvereid 2007). The entrepreneurs in this study had to a large extent been "learning from others" (Eriksson et al. 1997) in the form of formal education. However, even the informants who had been studying in Asia (A, B, E, G) regarded this educational knowledge as a supplement, only providing some basics for business and entrepreneurship. The benefits of formal education underlined in previous studies (Shane 2003; Vinogradov and Kolvereid 2007) were thus not confirmed. This indicated that absence of education effects may, however, be explained by their international orientation (Dichtl et al. 1990) being developed in other ways. All of them had traveled a lot, and six (A, B, D, E, F, G) out of these seven entrepreneurs had previous work and/or study experiences from Hong Kong, mainland China, or other parts of the world before starting their businesses. This study thus 
contributes to internationalization theory by indicating that personal international experiences, like international travel and living abroad, downplay the importance of formal education in the ability to identify and develop transnational entrepreneurial opportunities. It furthermore seems likely that personal experiences and capabilities of this kind are more frequently found among immigrants from developed countries than among immigrants from less-developed countries, since traveling and living abroad is financially demanding. This difference further underlines the importance of addressing commonalities as well as differences among entrepreneurs in transnational entrepreneurship research.

The cases confirm that immigrants may be uniquely qualified as international entrepreneurs from the start in terms of international orientation by having a substantial experience and knowledge of two cultures (COO and COR) before starting their business, not the least as these two cultures usually make up their initial markets. Having learned many rules of the game (Ilhan-Nas et al. 2011), they know how to adapt both as individuals and on a firm level in relation to customers and suppliers (Johanson and Vahlne 2009). Their psychic distance and their liability of foreignness (Hymer 1976; Zaheer 1995) have thereby been reduced before starting the business.

Immigrant entrepreneurs are, however, often depicted as being driven into their entrepreneurship by negative circumstances, such as lack of knowledge and unemployment, that is, entrepreneurship by necessity rather than in response to an opportunity (Aliaga-Isla and Rialp 2013). This understanding is likely a consequence of the predominance of studies dealing with immigration from less-developed countries to advanced economies (Aliaga-Isla and Rialp 2013). The results of the present study differ, as the entrepreneurial incentives were opportunity based rather than necessity based (Aliaga-Isla and Rialp 2013). These entrepreneurs were not driven into entrepreneurship, but saw it as an attractive career endeavor (Gnyawali and Fogel 1994) entered into by choice, which likely is related to their origin in a developed economy and the human capital developed there. This finding therefore underlines the importance of separating various forms of transnational entrepreneurship to fully catch their nuances.

\section{Transnational opportunities and ventures}

Most entrepreneurship studies are unilocational in their spatial unit of analysis (Yeung 2002), and also, within international entrepreneurship multicountry studies are rare (Terjesen et al. 2016). In contrast, a transnational entrepreneur is by definition familiar with two different national contexts, and opportunities may be identified through comparisons between these two contexts. A prevalent characteristic of transnational entrepreneurship is opportunity recognition based on introducing processes or products to the COR familiar from the COO or based on use of the entrepreneurs' contacts in the home country (Portes et al. 2002). This study showed, however, that although this was the case for two entrepreneurs, others identified opportunities for acting in the opposite direction, that is, from their COR, Hong Kong, or neighboring China, to their COO, or they performed both import and export between these markets.

Notably, however, in the present study, a fourth category was also identified. For four of the entrepreneurs (A, E, F, G), the business idea was to facilitate international trade. By learning to master not only the context of their COO but also that of their COR and the neighboring China, they developed a competitive advantage implying an entrepreneurial opportunity in selling their talents (Tung 2008) to firms still lacking in these respects. 
Notably, this was achieved on the basis of non-financial resources (Kyle 1999); rather, they applied contextualized knowledge and cross-cultural bridging capabilities (Piaskowska and Trojanowski 2014) in smoothing business relationships that otherwise might have been threatened by cultural differences causing misunderstandings and other kinds of friction. Acting in a relationship-middlemen position, they provided institutional competence bridging psychic distances (Johanson and Vahlne 2009), thereby reducing the liability of foreignness (Hymer 1976; Zaheer 1995) affecting firms entering a foreign market. For their customers, this service functioned as a shortcut in otherwise very time-consuming relationship development processes.

Middleman entrepreneurs have been described as immigrants who "take advantage of ethnic resources such as language, networks, and skills to trade between their host and origin societies, while retaining their ethnic identity and non-assimilation stance as an integral part of their business strategy" (Drori et al. 2009, p. 1004). The business facilitators in our study also applied language and cultural skills, but in relationship-middleman positions, facilitating trade between their host and origin societies by selling the service of bridging cultural differences between the parties of a business relationship (customer and seller). This type of firm is likely quite common, especially for business exchange between culturally very separated markets. Nevertheless, these kinds of service opportunities have previously been left out of classifications (Landolt 2001) and studies (Sequiera et al. 2009). In fact, opportunity as a concept is often not defined or discussed in international entrepreneurship research (Mainela et al. 2014). This lack of attention is unfortunate, as opportunity has been put forward as the concept best capturing entrepreneurship as a research field (Murphy 2011), and since business-facilitating service opportunities likely represent an important potential for transnational entrepreneurship. Identifying this opportunity type thus represents an important contribution not only to transnational entrepreneurship research but also to international entrepreneurship theory. We therefore call for further studies of service opportunities, not the least studies addressing relationship-middleman positions.

These cases indicate that the cross-cultural bridging capability of transnational entrepreneurs is an important facilitator of early firm internationalization and an important dimension at the individual level, driving the early internationalization of firms. The transnational entrepreneurs in our cases initially focused on business exchange between the COO and COR, but they included additional country markets soon after inception. This finding illustrates that international migration contributes to increased global trade, starting from, but not limited to, business exchange between the COR and the COO. The findings furthermore broaden the scope of internationalization theory on born globals by showing that transnational entrepreneurs create born global firms, also for business models not based on technologically advanced products or services, that is, the kind of companies otherwise often associated with the born global concept (e.g., Freeman et al. 2006; Knight and Cavusgil 2004; Moen and Servais 2002; Rennie 1993; Welch et al. 2016).

Finally, the cases show that the business exchange can go in any direction between the $\mathrm{COO}$ and the COR. In other words, in the case of transnational entrepreneurs, there is no obvious "domestic market" from the start, as assumed in the dominating internationalization theories (e.g., Johanson and Vahlne 2009). This finding thus point at a gap in traditional internationalization theories and underlines the importance of developing theory addressing such gaps. It thereby motivates the emergence of transnational entrepreneurship as a theoretical domain, as transnational entrepreneurship in certain respects may follow a 
different logic than the one described in traditional internationalization theory (e.g., Johanson and Vahlne 1977, 2009).

\section{Institutional and cultural contexts}

In contrast to previous literature focusing on migration from less-developed countries to advanced economies (Aliaga-Isla and Rialp 2013), the present study takes context into account by focusing on entrepreneurs who have migrated from one developed economy (Sweden or Finland) to another developed economy (HKSAR). Mastering of two different cultural contexts gave our interviewees access to knowledge implying increased capabilities of opportunity identification (Shane 2000; Venkataraman 1997). These experiences moreover resulted in a competitive advantage, since learning to master contextual influences of different national cultures is a competence that is timeconsuming to develop (Zahra et al. 2005). This competitive advantage forms another, more positive, side of the coin of migration and drivers for transnational entrepreneurship than negative aspects like employment discrimination (e.g., Li 2001).

Identifying an opportunity is nevertheless not enough; a venture has to be formed if the opportunity is to be exploited. Our interviewees unanimously praised the regulative and normative institutional conditions in Hong Kong, which lends support to arguments that a business-favorable institutional environment facilitates and encourages entrepreneurship (Baumol et al. 2007; Hopp and Stephan 2012). All but one of these transnational entrepreneurs identified opportunities related to the neighboring mainland China, but chose to locate their businesses in Hong Kong for institutional reasons. This illustration of how the institutional context affects entrepreneurship contributes to filling a gap in entrepreneurship research that previously has left such factors understudied (Bruton et al. 2010).

The cases furthermore illustrate that experiences of two market contexts that are very different are likely to result in the ability to spot arbitrage opportunities related to import/ export of goods, and also service opportunities. The cognitive alertness capability of the interviewees had been developed by living in the two different contexts of the $\mathrm{COO}$ and the COR, and six entrepreneurs (A, C, D, E, F, G) identified services and products that were missing either on the Asian market or on the market in the $\mathrm{COO}$, while the seventh (B) sensed a demand in his $\mathrm{COO}$ for products he could find for a better price on the local markets in Hong Kong. These findings thus further stress the value of contextual, not the least cultural, knowledge, for spotting opportunities for international business.

\section{Limitations and practical implications}

As with all research, our study and findings come with limitations. This study was carried out among a limited number of entrepreneurs representing specific national contexts, which affects the generalizability of its results. Further studies of transnational entrepreneurs moving from and to developed economies are needed to test the generalizability of these findings and make transnational entrepreneurship theory more context sensitive. Moreover, addressing individual, firm, and contextual levels of analysis allowed for a holistic representation of transnational entrepreneurship, but this approach also implied a limited depth in the study of each of these levels.

Our findings illustrate that transnational entrepreneurs may make important contributions to the economic development of the local environment, but also that they are 
not a homogeneous group. Immigrants from developed economies are likely to differ from immigrants from less-developed economies in terms of human, social, cultural, and financial capital. Public support thus needs to be adapted to a variety of needs and ambitions. Furthermore, policymakers need to consider the institutional impact on entrepreneurship, as business-friendly institutions with low barriers for establishing and maintaining a business will attract, facilitate, and support entrepreneurship.

\section{Annex 1}

Table 4 Interview guide

Entrepreneurial and international background?

Educational background? (and languages)

Any family members who are/were entrepreneurs?

Previous experience of entrepreneurship?

Previous experience of foreign countries?

Previous experience of Asian cultures?

Why and how did you start your business in Hong Kong?

Initial intention with your entrepreneurship? Has it changed?

The length of stay in Hong Kong when you started your entrepreneurship?

When and how did you start your business?

Were you connected to any social networks?

The ownership of the company: sole or in partnership?

Entrepreneurial experience in HK?

Years operating this company?

Number of years since the first sales/export/import order/regularly exporting/importing/providing service?

Number of countries entered?

Number of countries of customers?

Number of employees?

The level of internationalization of the company?

Percent sales/country?

Institutional environment in Hong Kong?

Information about and support provided by state and local government before/while starting up/after startup? Support provided from other community groups prior to startup/while starting up/after startup?

Bank and/or investor support?

Registration and taxation issues and other regulations?

Any differences institution-wise between host and home countries?

Cultural environment in Hong Kong?

Experience of culture and business culture in general?

If experienced cultural distance — what difficulties/misunderstandings?

Experience of contacts with the local authorities?

Contacts with distributors/manufacturers and other parties in business? 
Open Access This article is distributed under the terms of the Creative Commons Attribution 4.0 International License (http://creativecommons.org/licenses/by/4.0/), which permits unrestricted use, distribution, and reproduction in any medium, provided you give appropriate credit to the original author(s) and the source, provide a link to the Creative Commons license, and indicate if changes were made.

\section{References}

Aldrich HE, Waldinger R (1990) Ethnicity and entrepreneurship. Annu Rev Sociol 16(1):111-135

Aliaga-Isla R, Rialp A (2012) How Do Information and Experience Play a Role in the Discovery of Entrepreneurial Opportunities? The Case of Latin-American Immigrants in Barcenlona. Lat Am Bus Rev 13(1):59-80

Aliaga-Isla R, Rialp A (2013) Systematic review of immigrant entrepreneurship literature: previous findings and ways forward. Entrep Reg Dev 25(9-10):819-844

Baumol WJ, Litan RE, Schramm CJ (2007) Good capitalism, bad capitalism, and the economics of growth and prosperity. Available at SSRN: https://ssrn.com/abstract=985843 or https://doi. org/10.2139/ssrn.985843

Bruton GD, Ahlstrom D, Li HL (2010) Institutional theory and entrepreneurship: where are we now and where do we need to move in the future? Entrep Theory Pract 34(3):421-440

Chandra Y, Styles C, Wilkinsson I (2009) The recognition of first time international entrepreneurial opportunities: evidence from firms in knowledge-based industries. Int Mark Rev 26(1):30-61

Chiles TH, Bluedorn AC, Gupta VK (2007) Beyond creative destruction and entrepreneurial discovery: a radical Austrian approach to entrepreneurship. OrgStud 28(4):467-493

Cloninger PA, Oviatt B (2007) Service content and the internationalization of young ventures: an empirical test. Entrep Theory Pract 31(2):233-256

Coviello NE (2006) The network dynamics of international new ventures. J Int Bus Stud 37(5):713-731

Cumming D, Sapienza HJ, Siegel DS, Wright M (2009) International entrepreneurship: managerial and policy implications. Strateg Entrep J 3(4):283-296

Dana L, Morris M (2007) Towards a synthesis: a model of immigrant and ethnic entrepreneurship. In: Dana L (ed) Handbook of research on ethnic minority entrepreneurship: a co-evolutionary view on resource management. Edward Elgar, Cheltenham, pp 803-811

Delmar F, Shane S (2003) Does business planning facilitate the development of new ventures? Strateg Manag J 24(12):1165-1185

Dichtl E, Koeglmayr HG, Mueller S (1990) International orientation as a precondition for export success. J Int Bus Stud 21(1):23-40

Drori I, Honig B, Ginsberg A (2006) Transnational entrepreneurship: toward a unifying theoretical framework. Acad Manag Proc 2006(1):Q1-Q6

Drori I, Honig B, Wright M (2009) Transnational entrepreneurship: an emergent field of study. Entrep Theory Pract 33(5):1001-1022

Dubois A, Gadde LE (2002) Systematic combining: an abductive approach to case research. J Bus Res 55(7): 553-560

Dyer JH, Singh H (1998) The relational view: cooperative strategy and sources of interorganizational competitive advantage. Acad Manag Rev 23(4):660-679

Emontspool J, Servais P (2017) Cross-border entrepreneurship in a global world: a critical reconceptualisation. Eur J Int Manag 11(3):262-279

Eisenhardt KM (1989) Building theories from case study research. Acad Manag Rev 14(4):532-550

Eisenhardt KM, Graebner ME (2007) Theory building from cases: opportunities and challenges. Acad Manag J 50(1):25-32

Elo M, Freiling J (2015) Transnational entrepreneurship: an introduction to the volume. Am J Entrep 8(2):1-8

Elo M, Riddle L (2016) Diaspora business. Inter-Disciplinary Press, Oxford

Eriksson K, Johanson J, Majkgård A, Sharma DD (1997) Experiential knowledge and costs in the internationalization process. J Int Bus Stud 28(2):337-360

Etemad H (2004) International entrepreneurship as a dynamic adaptive system: towards a grounded theory. J Int Entrep 2(1-2):5-59

Etemad H (2016) International entrepreneurship as a young field of scholarly inquiry and its relationship with the knowledge network of five related disciplines. J Int Entrep 14(2):157-167

Freeman S, Edwards R, Schroder B (2006) How smaller born-global firms use networks and alliances to overcome constraints to rapid internationalization. J Int Mark 14(3):33-63 
George NM, Parida V, Lahti T, Wincent J (2016) A systematic literature review of entrepreneurial opportunity recognition: insights on influencing factors. Int Ent Manag J 12(2):309-350

Gnyawali DR, Fogel DS (1994) Environments for entrepreneurship development: key dimensions and research implications. Entrep. Theory Pract 18:43-43

Guba EG, Lincoln YS (1994) Competing paradigms in qualitative research. In: Denzin NK, Lincoln YS (eds) Handbook of qualitative research. Sage, London, pp 163-194

Hilmersson M, Papaioannou S (2015) SME international opportunity scouting - empirical insights on its determinants and outcomes. J Int Entrep 13(3):186-211

Hofstede G (2010) The GLOBE debate: back to relevance. J Int Bus Stud 41(8):1339-1346

Hofstede G (1980) Motivation, leadership, and organization: do American theories apply abroad? Org Dyn 9(1):42-63

Hopp C, Stephan U (2012) The influence of socio-cultural environments on the performance of nascent entrepreneurs: community culture, motivation, self-efficacy and start-up success. Entrep Reg Dev 24(9-10):917-945

Hymer S (1976) The international operations of national firms: a study of direct foreign investment. MIT Press, Boston

Ilhan-Nas T, Sahin K, Cilingir Z (2011) International ethnic entrepreneurship: antecedents, outcomes and environmental context. Int Bus Rev 20(6):614-626

Johanson M, Martín OM (2015) The incremental expansion of born internationals: a comparison of new and old born internationals. Int Bus Rev 24(3):476-496

Johanson J, Mattsson L-G (1987) Interorganizational relations in industrial systems - a network approach compared with the transaction cost approach. Int Stud Manag Org 17(1):34-48

Johanson J, Vahlne JE (1977) The internationalization process of the firm - a model of knowledge development and increasing foreign market commitments. J Int Bus Stud 8(1):23-32

Johanson J, Vahlne JE (2009) The Uppsala internationalization process model revisited: from liability of foreignness to liability of outsidership. J Int Bus Stud 40(9):1411-1431

Jones MV, Coviello N, Tang YK (2011) International entrepreneurship research (1989-2009): a domain ontology and thematic analysis. J Business Venturing 26(6):632-659

Kirzner I (1973) Competition and entrepreneurship, 1st edn. University of Chicago Press, Chicago

Kirzner I (1979) Perception, opportunity, and profit: studies in the theory of entrepreneurship. University of Chicago Press, Chicago

Klapper L, Laeven L, Rajan R (2004) Business environment and firm entry: evidence from international data (No. w10380). National Bureau of Economic Research, Washington DC

Knight GA, Cavusgil ST (2004) Innovation, organizational capabilities, and the born-global firm. J Int Bus Stud 35(2):124-141

Kloosterman R (2000) Immigrant entrepreneurship and the institutional context: a theoretical exploration. In: Rath J (ed) Immigrant businesses, the economic, politico-institutional and social environment. Macmillan, Basingstoke, pp 90-106

Kontinen T, Ojala A (2011) International opportunity recognition among small and medium-sized family firms. J Small Bus Manag 49(3):490-514

Kyle D (1999) The Otavalo trade diaspora: social capital and transnational entrepreneurship. Ethnic Racial Stud 22(2):422-446

Landolt P (2001) Salvadoran economic transnationalism: embedded strategies for household maintenance, immigrant incorporation, and entrepreneurial expansion. Glob Netw 1(3):217-242

Lee N (2015) Migrant and ethnic diversity, cities and innovation: firm effects or city effects? J Econ Geog 15(4):769-796

Li PS (2001) Immigrants' propensity to self-employment: evidence from Canada. Int Migr Rev 35(4):1106-1128

Lincoln YS, Guba EG (1985) Naturalistic inquiry, vol 75. Sage, Newbury Park

Madsen TK, Servais P (1997) The internationalization of born globals: an evolutionary process? Int Bus Rev 6(6):561-583

Mainela T, Puhakka V (2009) Organising new business in a turbulent context: opportunity discovery and effectuation for IJV development in transition markets. J Int Entrep 7(2):111-134

Mainela T, Puhakka V, Servais P (2014) The concept of international opportunity in international entrepreneurship: a review and a research agenda. Int J Manag Rev 16(1):105-129

Meir A, Baskind A (2006) Ethnic business entrepreneurship among urbanising Bedouin in the Negev, Israel. Nomad People 10(1):71-100

Merrilees B, Miller D, Tiessen J (1998) Serendipity, leverage and the process of entrepreneurial internationalization. Small Enterp Res 6(2):3-11 
Moen Ø, Servais P (2002) Born global or gradual global? Examining the export behavior of small and medium-sized enterprises. J Int Mark 10(3):49-72

Mok KH (2005) Fostering entrepreneurship: changing role of government and higher education governance in Hong Kong. Res Pol 34(4):537-554

Murphy PJ (2011) A $2 \times 2$ conceptual foundation for entrepreneurial discovery theory. Entrep Theory Pract 35(2):359-374

Oviatt BM, McDougall PP (1994) Toward a theory of international new ventures. J Int Bus Stud 25(1):45-64

Piaskowska D, Trojanowski G (2014) Twice as smart? The importance of managers' formative-years' international experience for their international orientation and foreign acquisition decisions. Br J Manag 25(1):40-57

Peiris IK, Akoorie ME, Sinha P (2012) International entrepreneurship: a critical analysis of studies in the past two decades and future directions for research. J Int Entrep 10(4):279-324

Portes A, Guarnizo LE, Haller WJ (2002) Transnational entrepreneurs: an alternative form of immigrant economic adaptation. Am Sociol Rev 67:278-298

Pratt MG (2009) For the lack of a boilerplate: tips on writing up (and reviewing) qualitative research [editors' advice]. Acad Manag J 52(5):856-862

Rennie MW (1993) Born global. McKinsey Q 4:45-53

Sasse G, Thielemann E (2005) A research agenda for the study of migrants and minorities in Europe. J Common Mark Stud 43(4):655-671

Sequeira JM, Carr JC, Rasheed AA (2009) Transnational entrepreneurship: determinants of firm type and owner attributions of success. Entrep Theory Pract 33(5):1023-1044

Shane SA (2003) A general theory of entrepreneurship: the individual-opportunity nexus. Edward Elgar, Cheltenham

Shane S (2000) Prior knowledge and the discovery of entrepreneurial opportunities. Org Sci 11(4):448-469

Shane S, Venkataraman S (2000) The promise of entrepreneurship as a field of research. Acad Manag Rev 25(1):217-226

Tang J (2008) Environmental munificence for entrepreneurs: entrepreneurial alertness and commitment. Int J Entrep Behav Res 14(3):128-151

Terjesen S, Elam A (2009) Transnational entrepreneurs' venture internationalization strategies: a practice theory approach. Entrep Theory Pract 33(5):1093-1120

Terjesen S, Hessels J, Li D (2016) Comparative international entrepreneurship: a review and research agenda. J Manag 42(1):299-344

Timmons J, Spinelli S (2004) New venture strategies: entrepreneurship for the 21st century. Irwin-McGrawHill, Burr Ridge

Tung RL (2008) Brain circulation, diaspora, and international competitiveness. Eur Manag J 26(5):298-304

Venkataraman S (1997) The distinctive domain of entrepreneurship research. Adv Entrep Firm Emerg Growth 3(1):119-138

Vinogradov E, Jørgensen EJB (2017) Differences in international opportunity identification between native and immigrant entrepreneurs. J Int Entrep:1-22

Vinogradov E, Kolvereid L (2007) Cultural background, human capital and self-employment rates among immigrants in Norway. Entrep Reg Dev 19(4):359-376

Viswanathan M, Rosa JA (2007) Product and market development for subsistence marketplaces: consumption and entrepreneurship beyond literacy and resource barriers. In: Rosa JA, Viswanathan M (eds), product and market development for subsistence marketplaces. Advances in Int Manag, vol. 20. Emerald Group, Bingley 1-17

Welch LS, Luostarinen R (1988) Internationalization: evolution of a concept. Int Firm 14:83-98

Welch C, Piekkari R, Plakoyiannaki E, Paavilainen-Mäntymäki E (2011) Theorising from case studies: towards a pluralist future for international business research. J Int Bus Stud 42(5):740-762

Welch C, Rumyantseva M, Hewerdine LJ (2016) Using case research to reconstruct concepts: a methodology and illustration. Org Res Method 19(1):111-130

Welter F (2012) All you need is trust? A critical review of the trust and entrepreneurship literature. Int Small Bus J 30(3):193-212

Welter F (2011) Contextualizing entrepreneurship - conceptual challenges and ways forward. Entrep Theory Pract 35(1):165-184

Wong LL, Ng M (2002) The emergence of small transnational enterprise in Vancouver: the case of Chinese entrepreneur immigrants. Int J Urban Reg Res 26(3):508-530

Yeung HWC (1995) Qualitative personal interviews in international business research: Some lessons from a study of Hong Kong transnational corporations. Int Bus Rev 4(3):313-339 
Yeung HWC (2002) Entrepreneurship in international business: an institutional perspective. Asia Pac J Manag 19(1):29-61

Yin RK (2013) Case study research: design and methods. Sage, Thousand Oaks

Yu TFL (1998) Adaptive entrepreneurship and the economic development of Hong Kong. World Dev 26(5): 897-911

Zaheer S (1995) Overcoming the liability of foreignness. Acad Manag J 38(2):341-363

Zahra SA, Korri JS, Yu J (2005) Cognition and international entrepreneurship: implications for research on international opportunity recognition and exploitation. Int Bus Rev 14(2):129-146

Zhang M, Gao Q, Cho HS (2017) The effect of sub-national institutions and international entrepreneurial capability on international performance of export-focused SMEs: evidence from China and South Korea. J Int Entrep 15(1):85-110

Zhou M (2004) Revisiting ethnic entrepreneurship: convergencies, controversies, and conceptual advancements. Int Migr Rev 38(3):1040-1074

Zucchella A, Palamara G, Denicolai S (2007) The drivers of the early internationalization of the firm. J World Bus 42(3):268-280 